УДК: 726.82711 .57

ББК: 85.118

A43

DOI: $10.18688 /$ aal $17-2-19$

Antonis Tsakalos

\title{
Transforming Excavation Finds into Museum Exhibits: Examples from the Byzantine and Christian Museum, Athens
}

\author{
"Every single museum decision is a philosophical act \\ which arises from a cultural context and has cultural implications." \\ Suzan Pearce [30, p.49]
}

The main theme of the VII International Conference in 2016, as it was announced in the Call for papers, focuses on the 'art object', from the moment of its creation till the time of its actual presentation to the viewers. The idea is that the life of an artefact starts at the moment of its creation, but its real discovery happens at the time of its archaeological acquisition and of its presentation to the public, usually in a museum exhibition. Artifacts - objects shaped by human workmanship and presenting a historical or archaeological interest - usually have their own 'cycle of life' which is not merely linear. On the contrary, the very personal 'biography' of each artifact is multileveled and presents a development in the course of time, from the moment of its construction until its presentation (the most recent one, but not necessarily the last) in a museum, bearing numerous and varied information, values, and meanings. In every step of this long life, the artifact may acquire different uses and meanings, according to the corresponding historical, social, and ideological context [33; 34; 23, pp. 56-57]. This paper focuses on several examples of the multilayered and fascinating procedure of 'transforming' the excavation finds into museum exhibits. All the case-studies presented here have been selected among the different indoor and outdoor exhibitions of the Byzantine and Christian Museum in Athens, Greece ${ }^{1}$.

The Byzantine and Christian Museum (hereinafter: B.C.M.) is an old cultural institution counting more than 100 years of life and activities [18, pp.9-20; 24, pp.4-15]. Its permanent exhibitions have been recently re-designed according to modern museological and museographical concepts on the occasion of the opening of new exhibition galleries on two consecutive periods of time: in 2004 (exhibition of the Early Christian and Byzantine period), and in

1 I would like to thank the Organizing Committee of the VII Actual Problems of Theory and History of Art International Conference (2016) for publishing my paper. I also wish to thank the Byzantine \& Christian Museum's director, Dr. Aikaterini Dellaporta, for giving me the permission to publish this material, as well as Dr. Maria Borboudaki, Head of the Department of the Archaeological Collection of Sculpture, Wood Carving, Pottery, Minor Arts, Coins, Textiles and Canvases. All photos are taken by the author. 
2009 (post-Byzantine period) [19, pp. 13-27; 18, pp. 20-25; 24, pp. 17-31]. Additionally, in the year 2017, after three years of work by a team of archaeologists, architects, museologists, and plant designers, the Gardens of the Museum are ready to open to the public (Ill.32) for visits in an attractive green space in the centre of Athens with several small open-air exhibitions on the main topic of 'Paradise', such as an exhibition concerning the river Ilissos that was passing nearby, or an exhibition with architectural sculptures, some of them decorated with paradisal motifs (like the foliate cross, the Tree of Life, peacocks, etc.).

Both in the indoor and outdoor exhibitions of the B.C.M., the Christian beliefs on death and afterlife are well approached by archaeological material from excavations, such as tombs and kterismata (votive offerings). The link between the notions of death and Paradise is quite obvious: according to Christian beliefs, death is a passage from the corruptible and material world to eternal life. It is considered to be a long sleep in anticipation of the resurrection at the time of Christ's Second Coming, when the gate of Paradise shall open to welcome the righteous. The presentation of those examples reveals the curators' effort to present the archaeological finds in context, by keeping as much information concerning their discovery and their integration in a museum exhibition as possible.

In the gardens of the B.C.M., the visitors can see, among others, a group of three Early Christian tombs (Ill. 33). They were uncovered in 1996-97 during the construction works of the Athens metropolitan railway. The excavations revealed part of an ancient cemetery with 64 tombs dating from different periods (from the Archaic, $7^{\text {th }}-6^{\text {th }}$ century BC, till the Late Roman/Early Christian period, $3^{\text {rd }}-6^{\text {th }}$ century AD). It was decided that three of the Christian tombs should be detached from the excavation site at the area called Koukaki, not far from the well-known temple of Olympian Zeus in the centre of Athens, in order to be transported to the B.C.M. and to be included in its open-air exhibitions. Before being removed, the tombs were studied by the archaeologists of the excavation, who also provided a full documentation of photos, sketches, etc. Moreover, the tombs underwent specialized cleaning, stabilization and conservation work in situ by a group of restorers and technicians. For their removal, holes were drilled at a safe depth beneath each tomb in order to insert a special metal grid. The metal base and an external packaging assured the safe removal of the tombs and their transportation by crane from the excavation site to the Museum in $1998^{2}$ (Fig. 1).

As it concerns the actual presentation of the tombs at the B.C.M., the exhibition area in the gardens has been designed to be accessible not only to walking visitors, but also to visitors on wheel-chairs and to blind people, as it is also the case in all the interior and the exterior spaces of the Museum (Fig. 2). High but discreet metallic constructions supporting transparent glass roofs contribute to the protection of the tombs (Fig. 3). Specially designed freestanding panels contain photos and brief informative texts (all bilingual: in Greek and English), about the cemetery from where the tombs were detached, the funerary rituals and the characteristics of the tombs of that period.

\footnotetext{
2 The transport by crane, in April 1998, was realized thanks to the collaboration of different departments of the Hellenic Ministry of Culture: the Ephorate of Byzantine Antiquities of Athens, which was responsible for the excavation, the Central department of Restoration and the Byzantine and Christian Museum.
} 


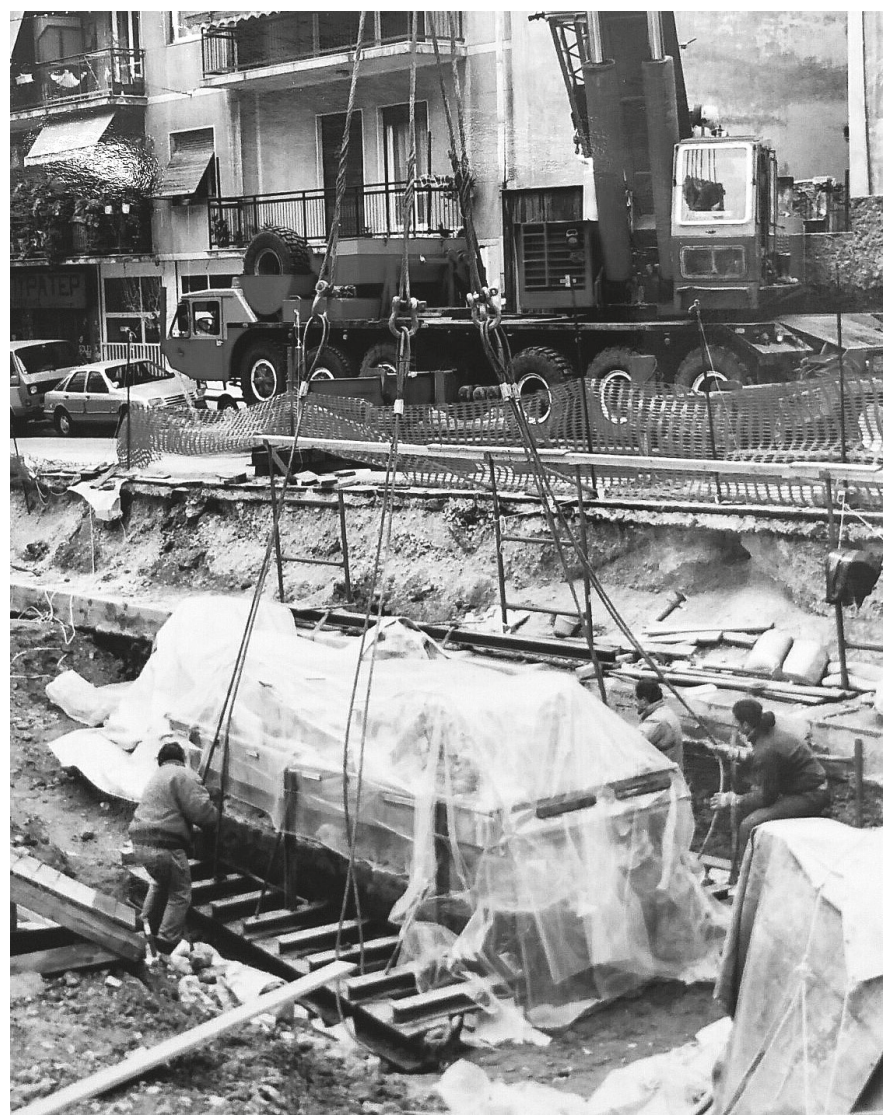

Fig. 1. Early Christian tomb transported by crane from the excavation site to the Byzantine \& Christian Museum, 1998

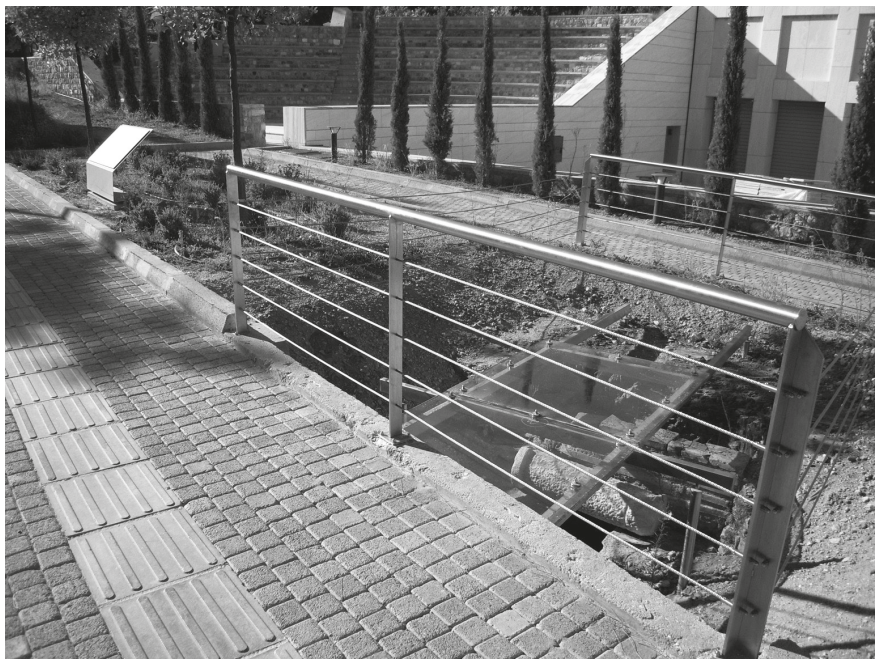

Fig. 2. Byzantine \& Christian Museum. Exhibition in situ of a Late Roman grave (ca. $3^{\text {rd }}$ century AD) uncovered in the Gardens in 2007. On the left: pathway marked for the blind 


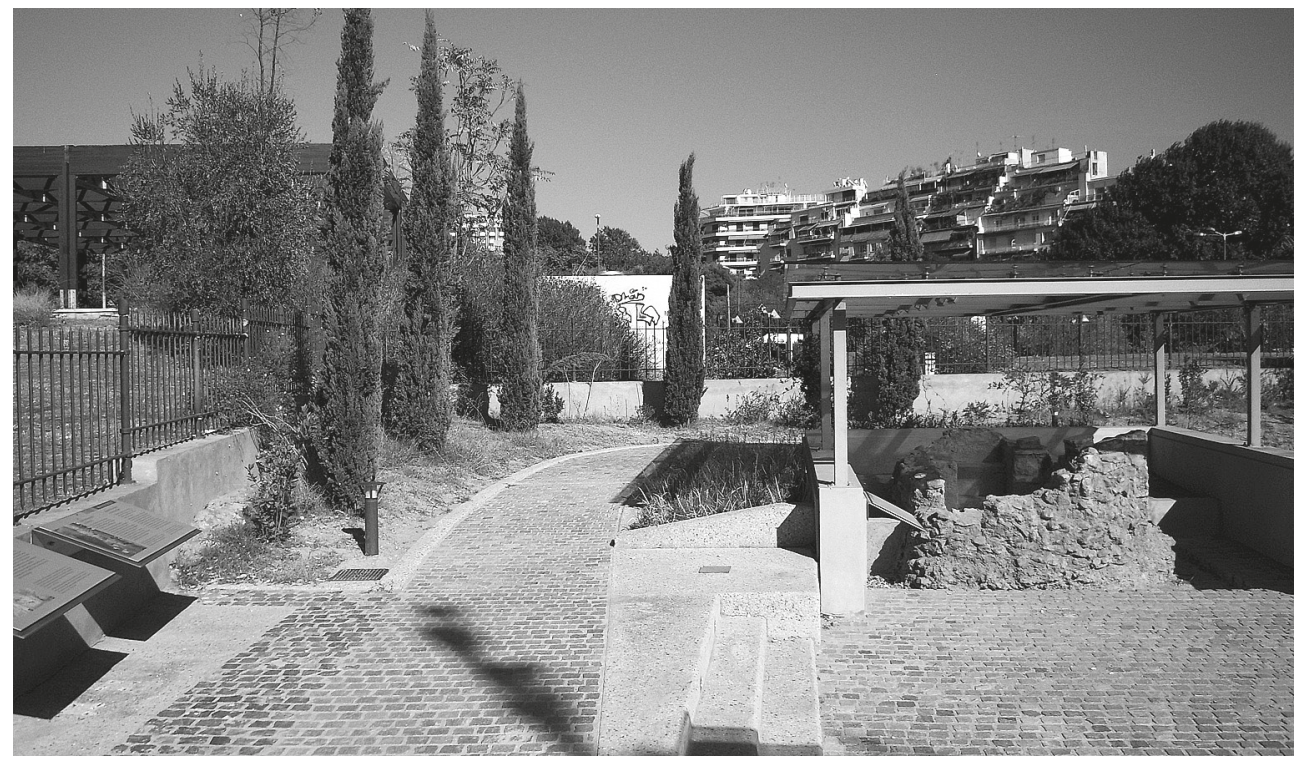

Fig. 3. Byzantine \& Christian Museum. Outdoor exhibition of three Early Christian tombs with glass roofs, freestanding informative panels and cypress trees

The three rectangular masonry tombs were vaulted and had three steps on the eastern side, which allowed to descend into the interior where a small number of kterismata was found, such as clay vases, bronze buckles, and a loom weight, apparently personal and beloved objects of the deceased $^{3}$. The texts on the panels briefly refer to several specific characteristics concerning the decoration or the structure of the tombs, such as the motif of a fish incised on certain slabs as a symbol of Christ; and the carved cross, still visible on the plastered inner walls, which declares the hope for eternal life and constitutes the most appropriate decoration for a tomb. On the floor slabs, several holes were facilitating the draining of organic fluids from the body of the deceased. Finally, a part of a Roman marble pedestal, representing a lion's foot, was incorporated into the side wall of a tomb and gave the curators the opportunity to inform the visitors on the common practice of reusing spolia in later monuments.

Regarding the vegetation in this area, cypress trees were planted around to recall the vegetation traditionally found in cemeteries (Fig. 3). Moreover, several pomegranate trees remind that this fruit is a symbol of abundance and eternity and, for this reason, it has been linked since antiquity with the idea of afterlife and the funerary rites.

Visitors are able to closely approach the front part of each tomb, while the back part gives the impression that it is still buried in the ground in order to remind of the original underground position of the tombs in the cemetery. It is worth noting that it has been decided not to remove the metal grid used for the safe transportation of one of the tombs to the museum. On the contrary, the modern structure was left intact and still remains visible under a specially 


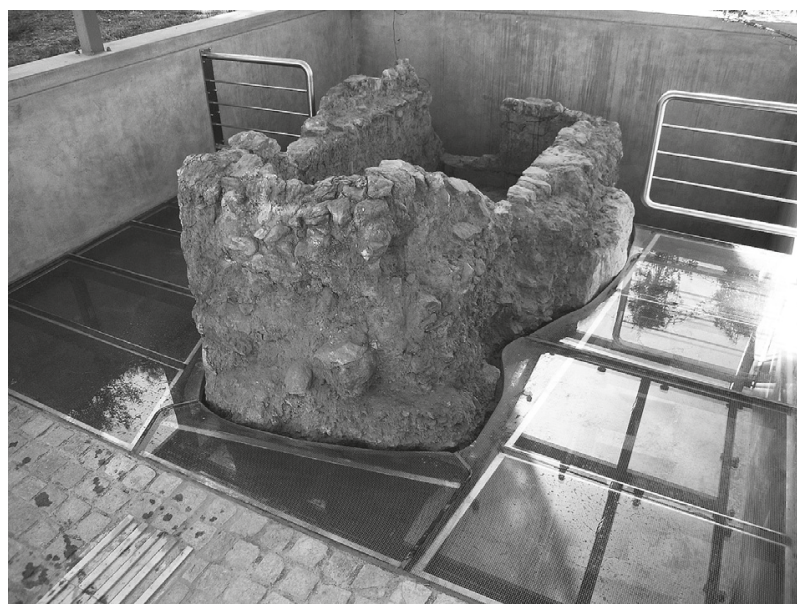

Fig. 4. Byzantine \& Christian Museum. Early Christian tomb: the transparent glass floor permits viewing of the metal grid used for its transport from the excavation site to the Museum designed transparent glass floor, on which the visitors can walk safely in close proximity to the tomb (Fig. 4). On a panel nearby, several photos, taken during the preparation and transportation of the tombs, allow the visitors to fully understand the procedure of discovering antiquities and transforming them into museum exhibits in order to present them to the public. It is obvious that the three tombs are not exhibited as mere artefacts, but their discovery and their installation in the museum are promoted as integral part of their own history. As it is widely accepted among the archaeologists, the excavations - no matter whether they are considered to be a creative or a destructive technique - mark the beginning of the archaeological interpretative process $[4 ; 13 ; 15]$.

An equivalent concept has been followed in several other cases in the B.C.M. Closely to the above-mentioned tombs, a Late Roman grave (probably from the $3^{\text {rd }}$ century AD) was uncovered during construction works carried out in the museum estate in 2007 (Fig. 2). The tomb had masonry walls and was covered with re-used architectural parts of an earlier structure, such as marble slabs and a small marble column. Unfortunately, all skeleton remains were destroyed and there is no indication on the religious beliefs of the deceased. Only four nails were found in the interior, indicating that the deceased probably was buried in a coffin. After the necessary conservation work, it has been decided that the tomb should be presented in situ, alongside with photos and texts, as part of the open-air exhibitions about death and afterlife. It is possible that a cemetery may have existed there, as suggested by archaeological evidence in the surrounding area, which was located extra muros, in antiquity ${ }^{4}$.

In the indoor permanent exhibitions of the B.C.M., a special section is devoted to the Christian beliefs about death and afterlife [19, pp.94-101; 24, pp.26-27]. In the thematic section entitled "In pastures green: Christians in the face of death", two Early Christian tombs, which probably belonged to a wealthy couple and were uncovered during excavations in the outskirts of Athens, are now presented as main exhibits in the middle of the room (Ill.34). They are accompanied by explanatory texts, drawings of the inscriptions and decorations of their interior walls, as well as photos from the time of their discovery outside the eastern part of the church. Thus, the tombs are fully documented and integrated in their archaeological and historical context. They have successfully been transformed into museum exhibits.

4 This area was located outside the city walls in antiquity and was largely excavated during the Athens metropolitan railway construction. For the excavation finds and the cemeteries uncovered in this area, see: [26]. 
Last but not least, the wellknown 'Mytilene Hoard' $\left(6^{\text {th }}\right.$ $7^{\text {th }}$ century $\mathrm{AD}$ ) is a precisely dated, closed deposit of silver vessels, gold jewelry, and coins; it occupies a prominent place in the permanent exhibition" ${ }^{5}$. The 'Mytilene Hoard' is of great artistic and historic importance, because its concealment can be dated towards the end of the third decade of the $7^{\text {th }}$ century, the period of turmoil for the empire brought on by the Persian and the AvaroSlavic invasions. It was during the construction of Lesvos Island airport in 1951 that the Treasure

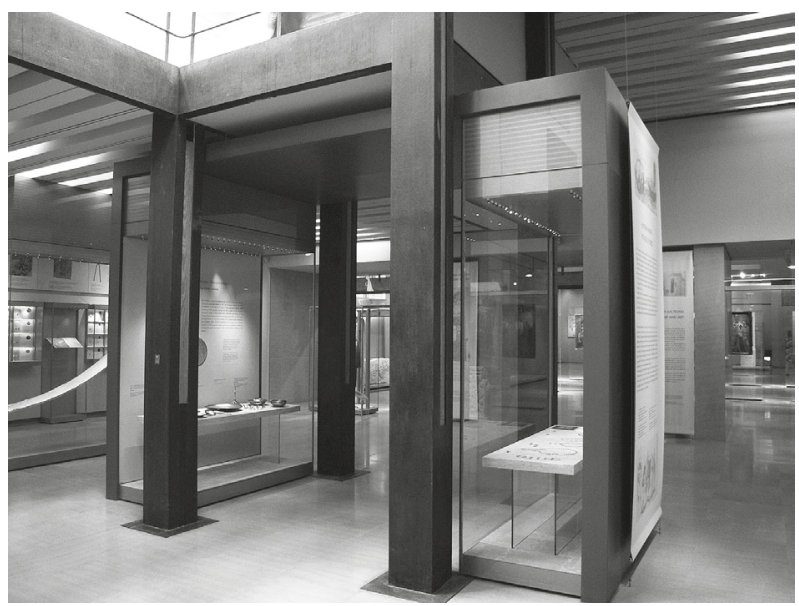

Fig. 5. Byzantine \& Christian Museum. Permanent exhibition. Group of two showcases containing gold and silver artefacts of the "Mytilene Hoard", $6^{\text {th }}-7^{\text {th }}$ century AD was found accidentally, like most hoards. In the permanent exhibition of the Byzantine \& Christian museum, the Hoard is presented in a set of two specially designed showcases that attempt to create an 'enclosed' space [19, pp. 113-117]. In the middle of a much bigger room, the visitors can walk between the two showcases that face each other, one containing silver vessels and the other gold coins and jewellery of the hoard (Fig. 5). The aim of that museographic approach is neither a realistic visual re-creation of the past, nor an illusion of a reconstructed reality. On the opposite, the intention is to remind, in a relatively abstract way, of the precious concealment of an object in the ground during several centuries by means of using modern materials and suggesting a contemporary aesthetic approach. This is an appropriate way of reminding of the discovery of objects during excavations and of the transformation of archaeological finds into museum exhibits in order to present them to the public 6 .

The term 'transformation' has been used in all the above-mentioned examples because, as it is obvious, no artefact or archaeological find was originally created to be exhibited in a museum [see also: 5, p. 109]. As Lewis R. Binford has pointed out, the archaeologists consider the artifact as a testimony of the consecutive realities in which it participated in the past (even if those realities are not easily apparent today). In the course of its life, an artifact accumulates on its material body traces of time and different events; in that way, the values of the past are conserved for the future [2]. Following Chris Gosden's [8] question "What do objects want?",

\footnotetext{
5 The decoration of the silver and gold artifacts by crosses and pagan motifs indicates that the Mytilene hoard's owners were obviously a family of high officials and were Christians, who therefore did not reject mythological and pagan subject matter. The latter contributes to our understanding of the Christianized aristocracy's aesthetic preferences during the $7^{\text {th }}$ century, and of the continuity and survival of pagan beliefs, foreign to the teachings of the new religion. On the Mytilene Treasure, see the monographic publication: [38].

6 On the museographic approach followed in the permanent exhibition of the Byzantine \& Christian Museum, see: [16, pp. 29-40].
} 
we can investigate what kind of information the material culture can give us, but also what archaeologists and museum curators want (or choose) to learn from the artifacts.

In their new status of exhibits, the objects should not be presented as mere artefacts or works of art. Indeed, a special attention should be paid so that they continue to reveal the aspects of their 'previous life'. In their new status, they shall be accompanied by information about the time and the context of their construction, their original function and use, but also about the reasons that put an end to their 'active" life (for example, a war or a natural disaster) and about the long period during which they were buried underground until the archaeological research brought them back to light. This procedure is quite important and very meaningful, especially if we take into account the role of the museums as vehicles of conservation (or reconstruction) of the past, traditions, collective memory and social identity ${ }^{7}$.

Selected among many others in order to be presented in a museum exhibition, an object is surely a material testimony of one or more human activities in the past, but it does not attest a unique and absolute truth; for that reason, more than one meaning or value may be attributed to it ${ }^{8}$. Apart from the standard technical information (for example, description, dimensions, provenance, date, etc.), the museum exhibit contains a wide range of information and has a story to tell'. It should not be neglected that, apart from the 'existing exhibit' and the accompanying information on it, the curator shall also pay attention to the 'missing exhibit', which may have been lost, destroyed, stored, or exhibited in a different place; it may be useful for the better understanding of the use of an object in a particular context.

According to Rosemary A. Joyce and Robert W. Preucel, the ancient artefacts did not emerge as a kind of "monologue" of the person who created them, but they were conceived and constructed through a procedure of a dialogue with the surrounding community and its members [15, pp.68-99]. Also, it is obvious that not every artifact can be presented in a museum. The exhibit has been selected among many others because of its "exhibitionnal value", following the term used by Michael Shanks [31, p. 33 $]^{10}$.

As Susan Pearce has pointed out, "every single museum decision is a philosophical act which arises from a cultural context and has cultural implications" [30, p. 49]. The selected examples from the various indoor and outdoor exhibitions of the Byzantine \& Christian Museum in Athens, which were briefly presented in this paper, may be inscribed in the frame of the recent museological and museographical tendencies. Nowadays, museums are expected to abandon the traditional or conservative forms of exhibition and communication and to establish more

\footnotetext{
7 The above-mentioned subjects are treated in many important studies, among which the following: $[4 ; 11 ; 21 ; 36$, pp. 20-22].

8 Among numerous texts and publications treating different methods for approaching and interpreting the material culture, the following are quite relevant: [12; 17; 35; 37].

9 According to Sandra Dudley [7, p. 9], the artifact's material identity consists of the object's form, the materials and the techniques used for its construction, all additions, changes or conservations that may have occurred, as well as all traces of the time passed and, in particular, of the human activity on it.

10 Among the main criteria for selecting an artifact to become an exhibit, one may mention the information provided to scientists, the aesthetic value, the symbolic value [20], as well as contribution to education or to tourism, inspiration to contemporary artists etc. [6, pp. 43-47]. For different lists of criteria concerning the management of the cultural heritage, as applied by national and international organizations, see: [3, pp. 148-176].
} 
interactive relationship with their visitors in order to have greater impact on the society and to fulfil their role as polyvalent cultural institutions ${ }^{11}$.

\section{References}

1. Bennett T. The Birth of the Museum: History, Theory, Politics. London; New York, Routledge Publ., 1995. $278 \mathrm{p}$.

2. Binford L.R. Data, Relativism and Archaeological Science. Man, New Series, 1987, vol.22, no.3, pp.391-404.

3. Carman J. Archaeology and Heritage: An Introduction. London, Continuum Publ., 2002. 227 p.

4. Carver M. Digging for Ideas. Antiquity, 1989, vol. 63, pp. 666-674.

5. Chourmouziadi A. From Finds to Exhibits. Anaskamma, 2010, vol.4, pp. 109-140 (in Greek).

6. Darvill T. Value Systems in Archaeology. Managing Archaeology. M. Cooper et al. (eds.). London; New York, Routledge Publ., 1995, pp. 40-50.

7. Dudley S. Museum Materialities: Objects, Sense and Feeling. Museum Materialities: Objects, Engagements, Interpretations, S. Dudley (ed.). London; New York, Routledge Publ., 2010, pp. 1-18.

8. Gosden C. What Do Objects Want? Journal of Archaeological Method and Theory, 2005, vol.12, no.3, pp. 193-211.

9. Greenberg R.; Ferguson B. W.; Nairne S. (eds.). Thinking about Exhibitions. London; New York, Routledge Publ., 1996. 487 p.

10. Hein G. Learning in the Museum. London; New York, Routledge Publ., 1998. 204 p.

11. Hobsbaum E. J.; Ranger T.O. (eds.). The Invention of Tradition. Cambridge, Cambridge University Press Publ., 1992. 320 p.

12. Hodder I. et al. (eds.). Interpreting Archaeology: Finding Meaning in the Past. London; New York, Routledge Publ., 1995. 275 p.

13. Hodder I. The Archaeological Process: An Introduction. Oxford, Blackwell Publ., 1999. 242 p.

14. Hooper-Greenhill E. Museums and the Shaping of Knowledge. London; New York, Routledge Publ., 1992. $232 \mathrm{p}$.

15. Joyce R.A. et al. (eds.). The Languages of Archaeology: Dialogue, Narrative and Writing. Oxford, Blackwell Publ., 2002. 176 p.

16. Katsanika-Stefanou E. The Museographical Proposal. Byzantine and Christian Museum, Byzantine Collections, The Permanent Exhibition. D. Konstantios (ed.). Athens, Byzantine and Christian Museum Publ., 2010, pp. 29-40.

17. Knappett C. Thinking through Material Culture: An Interdisciplinary Perspective. Philadelphia, University of Pennsylvania Press Publ., 2005. 216 p.

18. Konstantios D. (ed.). The World of the Byzantine Museum. Athens, Byzantine and Christian Museum Publ., 2004. $512 \mathrm{p}$.

19. Konstantios D. (ed.). Byzantine and Christian Museum, Byzantine Collections, The Permanent Exhibition. Athens, Byzantine and Christian Museum Publ., 2010. 228 p.

20. Lipe W. Value and Meaning in Cultural Resources. Approaches to the Archaeological Heritage: A Comparative Study of World Cultural Resource Management Systems. H. Cleere (ed.). Cambridge, Cambridge University Press Publ., 1984. pp.1-11.

21. Lowenthal D. The Past is a Foreign Country. Cambridge, Cambridge University Press Publ., 1985. 516 p.

22. Marki E. He necropolis tes Thessalonikis stous ysteroromaikous kai palaiochristianikous chronous (The Salonica Necropolis during the Late Roman and Early Christian Period). Athens, TAPA Publ., 2006. 246 p. (in Greek).

23. Mouliou M.; Bounia A. Museum Exhibitions: Interpretational Approach of the Museum Theory and Practice. Archaiologia (Archaeology), 1999, vol.70, pp. 53-58 (in Greek).

24. Moysidou J. (ed.). Byzantine and Christian Museum, The Permanent Exhibition. Athens, Byzantine and Christian Museum Publ., 2010. 96 p.

11 On the role of the museums: $[1 ; 9 ; 29 ; 27 ; 28]$. On the relationship and the communication established between the museum and its visitors: $[10 ; 14]$. 
25. Pallas D. The Christian Vaulted Tombs. Synagoge Meleton Byzantinis Archaiologias: techne - latreia - koinonia (Studies on Byzantine Archaeology: Art-Worship - Society), vol. 1. Athens, Hellenic Ministry of Culture Publ., 1987-1988, pp.318-336 (in Greek).

26. Parlama L.; Stampolidis N. (eds.). Athens: The City Beneath the City: Antiquities from the Metropolitan Railway Excavations (exhibition catalogue). Athens, Hellenic Ministry of Culture; N.P. Goulandris Foundation-Museum of Cycladic Art Publ., 2000. 416 p.

27. Pearce S. (ed.). Museums, Objects and Collections: A Cultural Study. Leicester; London, Leicester University Press Publ., 1992. 343 p.

28. Pearce S. On Collecting: An Investigation into Collecting in the European Tradition. London; New York, Routledge Publ., 1995. 287 p.

29. Pearce S. Experiencing Material Culture in the Western World. Leicester; London, Leicester University Press Publ., 1997. 274 p.

30. Pearce S. Studying Museums: New Needs and New Approaches. Archaiologia (Archaeology), 1999, vol.70, pp. 47-49 (in Greek).

31. Pearson M.; Shanks M. Theatre/Archaeology. London; New York, Routledge Publ., 2001. 243 p.

32. Pennas Ch. Early Christian Burials at Philippi. Byzantinische Forschungen, 1995, vol. 21, pp. 215-227.

33. Schaerer M. Museology: The Exhibited Exhibition - A Museological Experiment. Museum Management and Curatorship, 1994, vol. 13, no.2, pp.215-219.

34. Schaerer M. Museology: The Exhibited Man/Thing Relationship - A New Museological Experiment. Museum Management and Curatorship, 1996, vol. 15, no. 1, pp.9-20.

35. Schiffer M. B. (ed.). Advances in Archaeological Method and Theory. New York, Academic Press Publ., 1982. $539 \mathrm{p}$.

36. Shanks M.; Hodder I. Processual, Post-Processual and Interpretive Archaeology. Interpreting Archaeology: Finding Meaning in the Past. I. Hodder et al. (eds.). London; New York, Routledge Publ., 1995, pp. 3-29.

37. Thomas J. (ed.). Interpretive Archaeology: A Reader. London, Leicester University Press Publ., 2000. 423 p.

38. Touratsoglou I.; Chalkia E. The Kratigos, Mytilene Treasure. Coins and Valuables of the $7^{\text {th }}$ Century AD. Athens, Byzantine and Christian Museum Publ., 2008. 144 p.

Title. Transforming Excavation Finds into Museum Exhibits: Examples from the Byzantine and Christian Museum, Athens.

Author. Antonis Tsakalos - Ph. D., curator. Byzantine and Christian Museum, Vas. Sofias 22, 10675 Athens, Greece. antonistsakalos@gmail.com

Abstract. The life of an artefact starts at the moment of its creation, but its real discovery starts at the time of its archaeological acquisition and of its presentation to the public, usually in a museum exhibition. In every step of this long life, the artefact may acquire different uses and meanings, according to the corresponding historical, social, and ideological context. This paper focuses on several examples of the multi-layered and fascinating procedure of transforming the excavation finds into museum exhibits. All case-studies have been selected from the different indoor and outdoor exhibitions of the Byzantine and Christian Museum in Athens, Greece. In museum gardens, in the area with cypress trees traditional for cemeteries, the visitors can see three Early Christian tombs which were transported there by crane from the excavation site of an ancient cemetery. The metal structure used for the safe transportation of one of the tombs has been conserved and is still visible under the transparent ground level around the tomb. In combination with the information on cemeteries and photos showing the transportation of the tombs, it is possible for the visitors to fully understand the procedure between the discovery of antiquities and their presentation in a museum. Moreover, a Late Roman grave uncovered in the museum gardens is now presented in situ, accompanied by relevant photos and textual information. In the museum permanent exhibition, two Early Christian tombs are accompanied by explanatory texts and photos of their discovery during excavations, so that the finds/exhibits can be fully understood in their archaeological and historical context. Last but not least, the well-known 'Mytilene Hoard', $7^{\text {th }}$ century, is presented inside the set of two showcases facing each other in order to create an enclosed space, as an allusion to the secret concealment of precious objects in the ground. The above mentioned examples from the Byzantine and Christian Museum reveal the curators' effort to present the archaeological finds in context, by keeping as much information as possible concerning their discovery and their integration in a museum exhibition.

Keywords: Early Christian period; Christian tomb; excavation find; museum exhibition; museology; museography; Mytilene Hoard; Byzantine and Christian Museum; Athens. 
Название статьи. От археологических находок к музейным экспонатам. Примеры из Византийского и христианского музея в Афинах.

Сведения об авторе. Цакалос Антонис - Ph. D., хранитель. Византийский и христианский музей, ваз. Софиас 22, 10675 Афины, Греция. antonistsakalos@gmail.com

Аннотация. Бытование артефакта начинается в момент его создания, но его реальное открытие начинается во время его археологического приобретения и представления его публике, как правило, на музейной выставке. На каждом этапе этого долгого пути артефакт может приобретать различные виды использования и значения в соответствии с историческим, социальным и идеологическим контекстом. В этой статье рассматриваются несколько примеров увлекательного многослойного процесса «преобразования» результатов раскопок в музейные экспонаты из опыта экспонирования Византийского и христианского музея в Афинах (Греция) как на выставках внутри музея, так и в открытом пространстве вокруг него. В садах музея, в той части, где высажены кипарисы - деревья, традиционные для кладбищ, посетители могут увидеть три раннехристианские гробницы, доставленные туда с помощью крана с места раскопок древнего кладбища. Металлическая конструкция, используемая для безопасной транспортировки одной из гробниц, была сохранена и видна под прозрачным стеклом на уровне почвы. Благодаря размещению сведений о древних кладбищах и фотографий, показывающих транспортировку гробниц, посетители могут полностью проследить процесс от открытия памятников до их представления в музее. Кроме того, теперь в саду музея в сопровождении соответствующих фотографий и текстов экспонируется обнаруженное здесь же позднее римское захоронение. В постоянной экспозиции музея представлены два раннехристианских захоронения и пояснительные тексты и фотографии, снятые в момент их обнаружения во время раскопок, так что находки-экспонаты могут быть осмыслены посетителями как в историческом, так и в археологическом контексте. И последнее, но не менее важное: знаменитый «Митиленский клад» (VII в.) экспонируется внутри специальных витрин, создающих замкнутое пространство, что напоминает о том, как эти драгоценные предметы были сокрыты в земле. Рассмотренные примеры из Византийского и Христианского музея отражают усилия кураторов представить археологические находки в контексте, максимально сохраняя информацию об их обнаружении и интеграции в музейную экспозицию.

Ключевые слова: раннехристианский период; христианские гробницы; музейный экспонат, музейная экспозиция; музеология; музеография; Митиленский клад; Музей Византийский музей; Афины. 

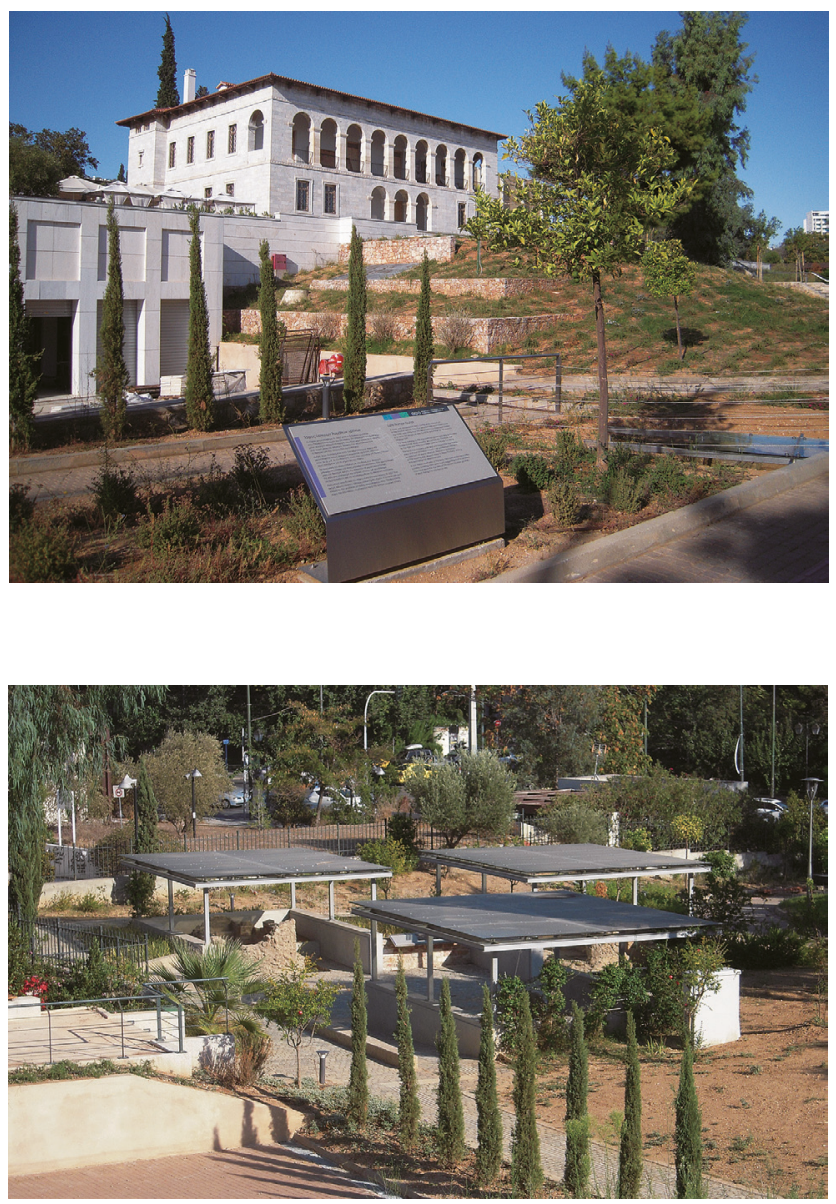

Ill. 33. Byzantine \& Christian Museum, Athens. Outdoor exhibition of three Early Christian tombs ( $3^{\text {rd }}-6^{\text {th }}$ centuries AD)
Ill. 32. Byzantine \& Christian Museum, Athens. General view of the main building and the gardens

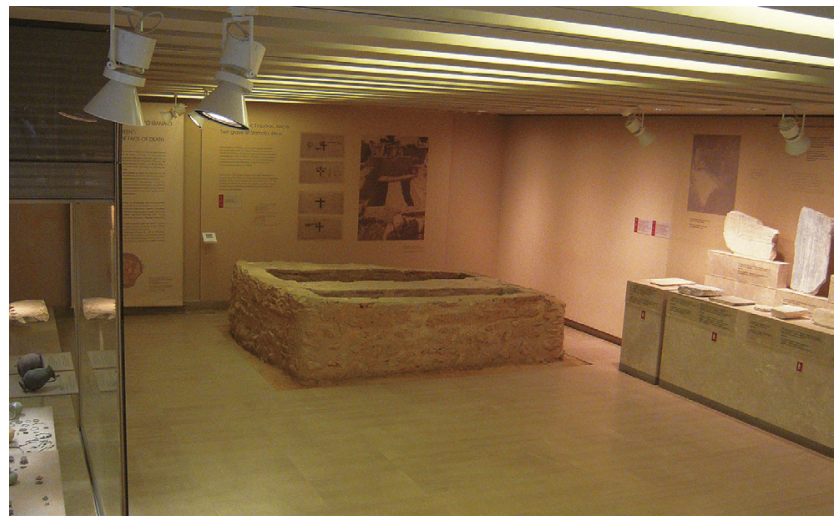

Ill. 34. Byzantine \& Christian Museum, Athens. Permanent exhibition. Thematic section: "Christians in the face of death" 